\title{
THE INTERNATIONAL INTELLECTUAL PROPERTY LAW SYSTEM: NEW ACTORS, NEW INSTITUTIONS, NEW SOURCES
}

\author{
GRAEME B. DINWOODIE*
}

It is now ten years since the Agreement on Trade-Related Aspects of Intellectual Property Rights (TRIPs) was concluded, subsuming that seemingly comprehensive intellectual property treaty into the institutional apparatus of the World Trade Organization (WTO). For many observers, TRIPs and the WTO established the framework of a new international intellectual property system. They were the center of the new system, into which other institutional components would feed, and from which other institutions would draw their agenda. The norms that TRIPs and the WTO articulated would inform all aspects of international intellectual property lawmaking. Indeed, around that time, a group of scholars published a collection of essays under the title GATT or WIPO?, contemplating the extent to which the WTO would displace the World Intellectual Property Organization (WIPO) as the dominant institution of international intellectual property law.

Ten years on, the answer to that question is neither the WTO, nor WIPO. It is the WTO

and WIPO;

and the practices of multinational information industry actors;

and technology that operates without regard to territory;

and national courts developing for the first time a private international law of intellectual property;

and new actors whose authority and remit are not linked to any particular nation-state;

and transnational networks of nongovernmental organizations (NGOs);

and existing international institutions that now find their work

* Professor of Law, Associate Dean, and Director of the Program in Intellectual Property Law, Chicago-Kent College of Law; Professor of Intellectual Property Law, Queen Mary College, University of London. This Lecture is a revised version of a lecture that was previously published in 98 AM. SOC'Y INT'L L. PROC. 213 (2004). It was also presented at the "The First Ten Years of the TRIPs Agreement" conference at Marquette University Law School in April 2005. 
impacted by intellectual property law.

The international intellectual property system has become a network of numerous institutions with many new actors, establishing and operating under new structures, and generating a welter of new norms. This is a much less convenient, much messier picture than the narrative of TRIPs as the central framework. But it is a fuller picture of the system by which intellectual property norms are generated and implemented internationally.

There is a danger that the elevation of TRIPs to the focal point of the system might create a myopia, distracting scholars and policymakers from attending fully to institutions and actors that are contributing to the internationalization of intellectual property law with as much (if not more) effect than TRIPs and the WTO. The internationalization of law comes about through many devices other than international law. It is therefore important that we adopt a broader vision of the international intellectual property system.

Of course, TRIPs has been and remains a vital component of the new international intellectual property system. Its adoption generated institutional competition with WIPO and gave birth to a useful range of alternative lawmaking devices. The enhanced protection that TRIPs ensured on a broader geographic scale raised the visibility of intellectual property rights and drew a broader range of actors into the public debate and the lawmaking process.

But TRIPs is only one component. In the first part of this lecture, I will highlight a few of the system's new institutions and lawmaking dynamics. Then I will suggest how we might reorient debates about the international intellectual property system in ways that allow us to strike a balance that many commentators feel is now lacking.

To begin with, however, in assessing the system, it is important to note that international intellectual property policymakers are engaged in an attempt simultaneously to strike two different balances. One balance, which likewise drives domestic intellectual property law, is that between private rights sufficient to incentivize creative behavior and third-party access to the fruits of that creativity so as to maximize its social value. But the incentives likely to maximize the production and dissemination of knowledge may vary from country to country, and thus international intellectual property law must attend to a second balance, one that occupies the attention of international law generally, and that is the balance between universal norms and the national autonomy necessary to legislate a substantive balance appropriate to each nationstate. 
With that metric in mind, let me briefly provide some examples of the new institutions I mentioned.

1) The Uniform Domain Name Dispute Resolution Policy (UDRP) adopted by the Internet Corportation for Assigned Names and Numbers (ICANN) in 1999 is perhaps the most notable example of private ordering that has mitigated the jurisdictional difficulties presented by the ubiquity of the Internet. The UDRP has become the international standard for resolving cybersquatting disputes.

Although ICANN's authority derives from an agreement with the U.S. Department of Commerce, it operates largely without reference to the laws of any particular nation. The UDRP shows that private actors, and actors that cannot be described using the traditional labels of "national," "international" or "supranational," may create "international intellectual property law" with virtually as much ease (and certainly as much effect) as nation-states.

Results in UDRP proceedings can, however, be overcome by contrary determinations in national courts. The UDRP is soft law. Yet in practice, "appeals" to national courts have rarely been invoked, and thus the UDRP has proven to be much harder law than theory would suggest.

2) The Digital Millennium Copyright Act 1998 (DMCA) immunizes an Internet service provider (ISP) from damages for copyright infringement where it hosts a subscriber's web site containing infringing material, provided that once the ISP receives a notice from a copyright owner reporting an alleged infringement, it expeditiously removes the infringing material.

Under the DMCA, ISPs have through their responses to such notices effectively served as first-instance adjudicators of disputes between copyright owners and users who post copyrighted content to websites. The practices of ISPs clearly have the capacity to support norms with respect to both the scope and enforcement of copyright.

Indeed, ISP practices under the DMCA are coming to establish international norms. U.S. copyright owners are serving notices on ISPs worldwide and receiving surprisingly high levels of compliance. Typically, extrusion of a country's law occurs through its application by courts, nominally restrained by private international law, a context that is both transparent and subject to contest by courts of other countries. These checks are lacking in the DMCA context.

Moreover, ISP practices may shift the balance between the application of national and international rules. Every aspect of the 
international regime implicitly allocates prescriptive authority. Where this balance is adjusted via ISP practices, however, the allocation might be the product of serendipitous forces largely related to the governance and client bases of multi-national ISPs rather than any publicly debated policy value.

3) Copyright owners increasingly use technological measures to protect their works against unauthorized acts, and international law imposes no limits on the type of measure owners can use. Like ISP practices, technology need not be territorially configured. Copyright owners may deploy protection measures that are tied to international rather than national norms. Alternatively, technological measures have the capability to reterritorialize international knowledge markets and implement national norms, and they can set norms without reference to either national or international norms. Private ordering thus can affect the structural norms of international copyright law: According to which set of values will the decision whether to universalize or territorialize be made? Again, we do not know, because this private ordering is subject to little or no scrutiny at any level, and certainly none at the international level.

Let me turn now to some of the ways existing institutions have revised their lawmaking operations. WIPO continues to be a primary institutional component of the new system, but it has reinvented itself. In addition to its traditional functions, WIPO has built relationships with many new actors. For example, it has signed a cooperation agreement with the WTO, facilitating the incorporation of WIPOcreated norms into the WTO process. Indeed, the WTO panel report in United States-Section 110(5) encouraged continuing integration by favoring the interpretation of TRIPs consistent with norms in the broader network of copyright treaties. This principle gives WIPO an ever-open entry point into the WTO system.

Similarly, the UDRP adopted by ICANN was drafted by WIPO, and WIPO's Arbitration Center is the primary administrator of the proceedings through which claims under it are resolved. Moreover, WIPO continues to be a leading forum for development of the UDRP, shaping the direction of those international standards in ways that ICANN's own internal review committee has been unable to achieve.

Finally, WIPO has recognized the changed nature of current demands for internationalization (made primarily by right holders):

(1) International solutions are now being sought more quickly. Some recent international instruments have articulated rather than codified norms, perhaps reflecting a fear that national practices may 
give rise to norms that would be hard to compromise internationally at a later date.

(2) The call for early international intervention has been accompanied by difficulty in achieving consensus among the more numerous and diverse members of the new system, especially without the possibility of non-intellectual property side payments that facilitated TRIPs.

Thus WIPO restructured itself institutionally to generate more soft law, such as non-binding recommendations adopted by its Standing Committee on Trademarks. These recommendations are accepted more speedily and provoke less entrenchment on the part of national delegations.

This soft law is hardened in many ways, but few of these involve the WTO. For example, the hardening of the UDRP arguably stems from its functional advantages to trademark owners. And standing committee resolutions have found their way into TRIPs-plus bilateral agreements, opinions of national jurists, and proposals for formal WIPO treaties, such as the proposed Revised Trademark Law Treaty.

Soft law is thus an important component of the new system, although its significance (and hardening) often depends upon interactions with parts of the system other than the WTO.

Trade arrangements remain important, however. As multilateral ministerial discussions have stalled, leading developed countries have pursued bilaterally harmonization agendas that cannot be achieved multilaterally. These bilateral agreements typically impose TRIPs-plus standards. They have therefore attracted the ire of critics who take issue with the substantive intellectual property balance that they embody, especially when imposed upon developing countries, whose immediate need for lesser protection is reflected in the continuing grace periods that permit delays in full implementation of the bare TRIPs standards.

Gains secured in a series of bilateral arrangements have commonly been consolidated through the multilateral device, and the United States has acknowledged this dynamic in explaining its bilateral strategy. Yet the introduction of most-favored nation obligations into international intellectual property law by the TRIPs Agreement may increase the momentum to move to the multilateral level. Problematically, too, a lack of transparency often attends bilateral negotiations.

Although bilateral agreements are not new, it is when they work in 
tandem with other institutional devices that the role of the bilateral in the new system becomes significant. Thus, bilaterals have become a means by which the United States seeks to harden the nonbinding resolutions of the WIPO Standing Committee on Trademarks regarding the protection of well-known marks. It is through bilateral negotiations that the United States is persuading countries to use the UDRP as a model for resolution of cybersquatting disputes in their country-code domain. Finally, bilaterals might break down the coalition of twenty developing countries that has blocked the U.S. multilateral agenda.

Indeed, a review of bilateral activity highlights a broader point: Even in the trade context, the shape of international intellectual property law is being determined by the interaction of numerous components of the system.

In addition to bilateralism, we must be alert to unilateralism. There should be no trade unilateralism after TRIPs, but here I want to use the term as an introduction to the increasingly important activities of national courts. Ten years ago, one could barely detect a private international law of intellectual property, either in the courts or in the literature.

In the classical system, national courts had very little role to play in the construction of international intellectual property law. Litigation involved national rights; courts were reluctant even to adjudicate claims involving foreign intellectual property rights, prompting serial national litigation of multinational disputes.

National courts are, however, beginning to tackle multinational cases and thus to contribute to the effective creation of international norms. This has occurred most perceptibly in the copyright context in the United States, where courts will now hear claims under foreign laws, provide multinational relief, and effectively regulate globally by localizing any Internet conduct in the United States.

These trends are less evident in patent cases, but U.S. courts have become less restrained in applying the Lanham Act extraterrorially. The enactment of the Anti-Cybersquatting Consumer Protection Act in 1999 has prompted even more intrusive U.S. judicial regulation of domain name space. Thus, private law developments in national courts increasingly generate the content of international intellectual property law.

How do we bring coherence to this dispersed, decentralized system? One might view this array of new actors, sources and institutions as intervening data points, all designed to feed back to a central institution, whether the WTO or WIPO. 
I resist this impulse. Such a dispersed system may possess advantages over the classical model. For example, national court development of "international law," like technological measures and ISP practices, can (if properly transparent and monitored) be more responsive to social conditions and hence more dynamic than the treaty process. Moreover, such lawmaking would not result in the premature entrenchment of a higher norm of international law in the way that WTO dispute settlement body rulings in practice might do. It is more readily subject to control by national political institutions. Moreover, this means of developing international intellectual property law is less subject to the political demands that historically have burdened the treaty process and that continue to limit its efficacy. Finally, such a mélange of national and international norms conforms to the decentralized yet interconnected structure of global society.

I also resist the effort to feed these developments back toward the multilateral treaty system, because it is inevitable that the non-treatybased system will effect internationalization more efficiently than the further development of TRIPs.

The interests at stake are now so varied, the reach of intellectual property law so wide, the demands of internationalization so strong, that it is hard to envisage an ambitious treaty on substantive norms that can obtain broad approval. In light of those same factors, plus burgeoning technological capacity and a proliferation of transnational actors (whether corporations, users, or NGOs), it is hard to see how a nontreaty system can be stopped.

The WTO will not, of course, recede into the darkness. So what is its role? Rochelle Dreyfuss and I have argued that dispute settlement panels must follow interpretive principles of neofederalism that preserve the autonomy of member states to adopt approaches tailored to their own circumstances. The formalism that TRIPs panels have exhibited thus far might, we fear, be used to limit autonomy and expand international obligations at a time when an impasse has been reached among negotiators of TRIPs II.

In the Ministerial context, Ruth Okediji has focused on the factors that affect coalition-building by developing countries to redress imbalances among states occasioned by power asymmetries and weak domestic institutions. Larry Helfer has explained how developing countries have engaged in regime-shifting to generate alternative substantive norms. Jerry Reichman and Keith Maskus propose a moratorium. The time has come, they say, "to take intellectual property off the international lawmaking agenda." Each of these proposals 
reflects a concern that the process toward universal standards is moving more quickly, and more definitively, than is advisable.

I am reluctant "to take intellectual property off the international lawmaking agenda." To be sure, under the classical model, multilateral agreements were built upon an evolving consensus. But the tide is running more strongly toward global solutions; for reasons of principle and pragmatism, we must react differently.

As a matter of principle, although internationalization may be occurring more quickly, and sometimes without the transparency or participation that is ideal, the exigencies of global trade and digital technologies require recalibration of the balance between national and international norms. To debate what that balance should be, we need information and institutional structures that allow choices to be made fairly and consciously. That is why the process of international intellectual property lawmaking should be a primary focus of attention.

Pragmatically, one cannot take intellectual property off the international lawmaking table because so much internationalization is taking place underneath the table. Reichman and Maskus hope that a moratorium would preserve the status quo and the autonomy with which nation-states are invested. Instead, it may simply defer to the different lawmaking institutions and actors already discussed. International lawmaking is necessary to ensure that these new processes occur transparently and in ways likely to produce the optimal balance that Reichman and Maskus seek to preserve. In short, there must still be a positive international intellectual property agenda.

What should that agenda be?

First, scholars and policymakers must recognize the inevitable and potentially useful ability of private actors, nonstate actors, technology, multinational corporations, and national courts to effect the internationalization of intellectual property norms.

Second, to ensure that these norms are developed with the same respect for voice and legitimacy that guided the development of the classical treaty-based system, attention must be paid to question of process, transparency, and representation. Transparency of private practices is essential if active national lawmaking is to act as a constraint on private ordering. What I have called "the public structuring" of private ordering becomes key. Rules must address the structural incentives for developing norms in one direction or another. And there must be a public allocation of certain issues to the national or the international realm. These questions are beginning to be addressed in scattered national, regional, and international instruments, but they 
must be given greater significance.

Third, in this decentralized system, the interaction between components may represent an important source of law. That interaction will help construct the balance between the national and the universal. For example, should national courts defer to UDRP panel opinions, or to other national courts addressing multinational disputes? Should they pay heed to the public international backdrop (whether in treaties or soft law) in interpreting the content and scope of national law?

In the context of national judicial relations, ongoing discussions may shape the answer to these questions. The Hague Conference on Private International Law continues to work on a jurisdiction and judgments convention that, although narrower than the treaty contemplated four years ago, would greatly enhance the role of national courts in the intellectual property system. Likewise, the American Law Institute (ALI) last year commenced a project to formulate soft law principles to guide courts in resolving international intellectual property disputes.

These specific examples highlight two conceptual points of focus for the international intellectual property system.

First, in an era in which substantive issues are often too contested to conclude treaties, but in which technology and global trade will force and facilitate international solutions, the focus of the international intellectual property law system has to be in large part on institutional design. The Hague and ALI projects would establish the basic conditions under which national courts could contribute to and develop a form of international intellectual property law. The international system has to create an environment in which that lawmaking is fair and balanced. That is, the process and structure of lawmaking must be addressed. This is true of the ways in which national courts contribute, but it is true also of how private actors contribute, how soft law contributes, how governmental and NGO networks contribute, and how intergovernmental organizations contribute.

Second, increasingly international intellectual property has to focus on constraints or checks on lawmaking. As Ruth Okediji has stressed, this is the classical role of international law, but I would emphasize that the constraints in question must address checks on more than simply national legislative activity.

Thus, the Hague Convention would empower national courts to do what they might in any event do unilaterally, but it would also constrain them, requiring them to articulate the reasons for their involvement in the international intellectual property system. Consolidation obligations (or even opportunities) in such a treaty might also operate 
as a constraint on multinational corporations exploiting the legal fiction of territoriality to secure strategic gains in multinational litigation.

In the context of private actors, international obligations of transparency and public structuring of the environment in which private ordering occurs might act as a constraint on the effective lawmaking of private actors.

National courts, themselves subject to constraints imposed by way of a jurisdiction convention, might be important checks on ICANN/UDRP panels pushing the mandate of anti-cybersquatting authority too aggressively in the face of legitimate national interests. (In fact, this dual role of national courts merely illustrates that the system will ultimately rely on different components checking each other).

Finally, international treaties might contain what I have called "substantive maxima" (what others have called "users' rights," and what might also be called "mandatory limits and exceptions") that would constrain national legislatures. Ideally, they would do so in ways akin to the role played by substantive minima in a century in which lack of any protection was a pre-dominant concern.

Thus designed, and thus constrained, this array of lawmaking institutions presents opportunities for reconfiguring the international intellectual property system in ways that strike the balance the system has always sought to promote, but in ways that reflect the more global nature of modern life. 